\title{
Venture Capital and Cleantech: The Wrong Model for Energy Innovation
}

\author{
Benjamin E. Gaddy \\ Clean Energy Trust, Chicago, IL 60606, USA \\ Varun Sivaram \\ Council on Foreign Relations, Washington, D.C. 20006, USA \\ Timothy B. Jones \\ TBJ Investments, LLC, Washington, D.C. 20003, USA \\ Libby Wayman \\ General Electric, Boston, MA 02111, USA
}

\begin{abstract}
Venture capital (VC) firms spent over $\$ 25$ billion funding clean energy technology (cleantech) start-ups from 2006 to 2011. Less than half of that capital was returned; as a result, funding has dried up in the cleantech sector. But as the International Energy Agency warns, without new energy technologies, the world cannot cost-effectively confront climate change. In this article, we present the most comprehensive account to date of the cleantech VC boom and bust. Our results aggregate hundreds of investments to calculate the risk and return profile of cleantech, and we compare the outcomes with those of medical and software technology investments. Cleantech posed high risks and yielded low returns to VCs. We conclude that among cleantech investments, "deep technology" investments - in companies developing new hardware, materials, chemistries, or manufacturing processes - consumed the most capital and yielded the lowest returns. We propose that broader support from policymakers, corporations, and investors is needed to underpin new innovation pathways for cleantech.

Keywords: Venture Capital, Energy, Cleantech
\end{abstract}

Preprint submitted to Energy Policy

October 21, 2016

(C) 2016. This manuscript version is made available under the Elsevier user license http://www.elsevier.com/open-access/userlicense/1.0/ 


\section{Introduction}

New energy technology will be needed to increase the likelihood of limiting global temperature increases to the $2^{\circ} \mathrm{C}$ ceiling and the $1.5^{\circ} \mathrm{C}$ goal set by the Paris Agreement of the United Nations Framework Convention on Climate Change (COP21). [1, 2] New innovations to reduce emissions of $\mathrm{CO}_{2}$ and capture $\mathrm{CO}_{2}$ will be required to avoid the most significant impacts of climate change. 3. However, new technologies face a so-called "valley of death" between government-supported research and commercialization. [4, 5] To bridge this gap, innovators frequently turn to venture capital (VC) investors to finance the early, high-risk stages of commercialization. [6] Over the last decade, VC investment in clean energy technology (cleantech) experienced a boom and bust. From 2004 to 2008 , VC investment in cleantech increased from approximately $\$ 1$ billion to $\$ 5$ billion, an average annual growth rate of 47\%. [7. (See Figure 1) But after 2008, funding dropped sharply, and the number of early-stage investments and the funding into those companies has remained low and approximately constant since.

However, recent announcements made at the 2015 Paris Climate Change Conference could enable a recovery in funding for cleantech research and development. Twenty countries around the world who have signed on to the Mission Innovation pledge to double public R\&D funding for advanced energy by 2020 . At the same time, the Breakthrough Energy Coalition - a group of wealthy investors led by Bill Gates - announced that they will invest billions of dollars to commercialize promising new energy innovations. For these efforts to succeed in moving breakthroughs from the lab to widespread deployment, it is vital not to repeat the mistakes from which the cleantech sector is still recovering.

This paper aims to first explain why VC investors scaled back their funding and second to offer suggestions for what the set of new actors in the sector might do differently to achieve better investment results. We use publicly available financing data of cleantech companies to evaluate how these VC investments performed in comparison with investments in software technology and 
medical technology. Our results show that early-stage investments in cleantech companies were more likely to fail and returned less capital than comparable investments in software and medical technology. Within the broad sector of cleantech, we demonstrate that investments in cleantech software returned capital to early investors, whereas investments in more fundamental hardware, materials, chemicals, and processes tended to lose money. Our data indicates that venture capital investors responded to the performance of their cleantech investments by reducing the total capital allocated to the sector, and by shifting investments from hardware and materials to cleantech software. We conclude by offering suggestions for how policymakers can better support emerging companies and prepare them for private-sector investment.

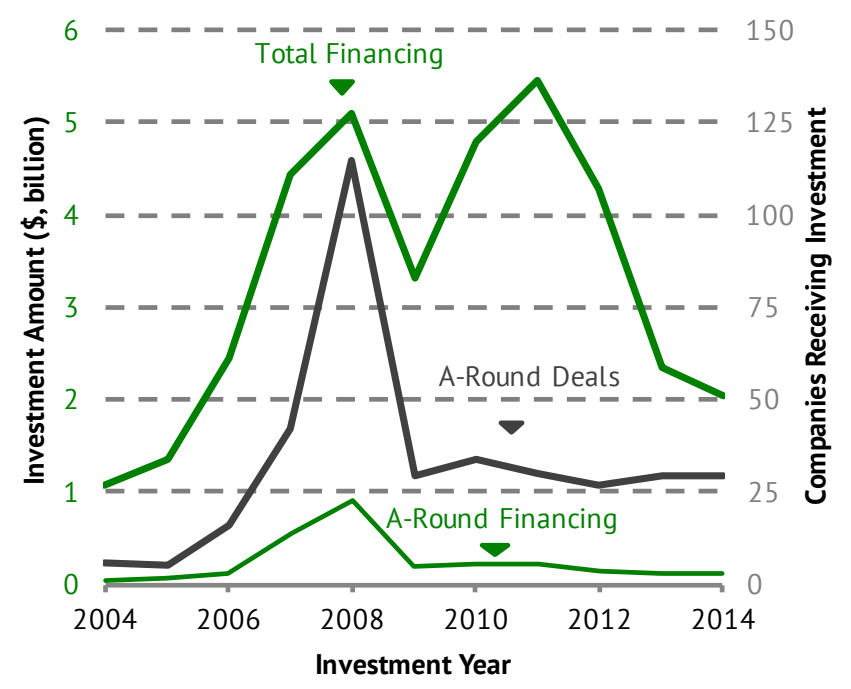

Figure 1: Venture capital activity in clean energy companies from 2004 to 2014, comparing trends in the total amount invested overall, the amount invested in early-stage (A-round) deals, and the total number of early-stage deals. 


\section{Background and Context}

\subsection{Overview of the cleantech sector from 2006 to 2011}

The cleantech sector gained considerable investor attention in the years before the investment peak of 2008. For the purposes of this study, we define cleantech companies as those which are commercializing clean energy technologies or business models, including those developing, integrating, deploying, or financing new materials, hardware, or software focused on energy generation, storage, distribution, and efficiency. Our analysis does not include other categories of non-energy "green" companies, including those focused on environmental waste management or non-energy-related water treatment.

A number of factors contributed to increased investor appetite for the sector, which rose sharply starting in 2006. Electricity prices in the United States rose $38 \%$ between 2002 and 2008, gasoline prices had approximately quadrupled from 1998 to 2008, and financial analysts predicted the price of a barrel of oil would continue rising - for example, Goldman Sachs forecasted a $\$ 200$ equilibrium price. 8, 9, 10, Elon Musk invested in the Series A round of Tesla Motors, an electric car maker, and joined its board in 2004 amid great fanfare. And, Al Gore released an Academy Award-winning film, An Inconvenient Truth, in 2006 increasing public concern about climate change.

Public policy began to reflect this growing interest in climate change and alternative energy. The Energy Policy Act, passed by the U.S. Congress in 2005, created the Investment Tax Credit and the Production Tax Credit-incentives for the deployment of solar, wind, and other renewables. 111 Later that year, the National Academy of Sciences released the first version of its report Rising Above the Gathering Storm in which it urged Congress to increase funding for energy RDD\&D (R\&D plus demonstration and deployment). It also proposed the Advanced Research Projects-Energy (ARPA-E), intended as an analogue to the Defense Advanced Research Projects Agency (DARPA), which was largely responsible for funding early work on the Internet and autonomous vehicles. [12] Congress responded by establishing ARPA-E in 2007 and it was funded two 
years later.

In late 2005, three solar companies went public at valuations above $\$ 100$ million (Q-Cells, SunPower, and Suntech) followed by a billion-dollar initial public offering by U.S. company First Solar in late 2006. Venture capital investors responded by hiring cleantech experts, forming sector-specific funds, and deploying considerable capital in the sector (Figure 1).

After the peak of investment in 2008, VC funding for cleantech fell sharply for early-stage companies, while investors continued to deploy capital into their existing portfolios through 2012. In 2012 alone, forty-five solar companies closed, filed for bankruptcy, or were sold under unfavorable terms, compared to eleven the year before. Failures like these led to the poor performance of $\mathrm{VC}$ portfolios discussed in this paper, resulting in decreased investment in the sector.

It is important to note the macroeconomic and policy factors which may affect investment returns independently from of the capability of individual firms. 13, 14. Among the macroeconomic trends that were of particular importance for cleantech firms were the financial crisis and credit crunch of 2008, the decline in oil and natural gas prices (attributed to slowing demand as well as increased supply enabled by hydraulic fracturing), and a glut in solar panel manufacturing capacity followed by a subsequent decline in the prices of solar modules. Policy played an equally important role in cleantech. [15] During this period, the failed attempts by the U.S. Congress to pass legislation limiting carbon emissions very likely had an effect on investor sentiment. In a later section, we note that a limitation of this study is uncertainty over the importance of exogenous factors in causing underperformance of the cleantech sector from 2006 to 2011. Nevertheless, it is likely that both poor company performance as well as exogenous factors contributed to observed cleantech returns - it therefore is sensible to extract lessons learned from this period to guide future support for the cleantech sector rather than betting that exogenous obstacles to cleantechs success will not recur. 


\subsection{Overview of Venture Capital Investor Role and Strategy}

Venture capital investors support risky new technologies by making investments in early-stage companies in exchange for an ownership stake in the company. [6] These investors can play a critical role in bridging the "valley of death" that new companies face when their emerging technology is too advanced to receive public basic research support but not yet mature technically or commercially. [4] VCs are particularly well suited to support the early stages of this maturation, during the technology and product development phases.

Venture capital funds are often structured as 10-year partnerships, where outside investors (the limited partners, or LPs) provide capital to the VC fund (run by the general partners, or GPs) to make high-risk, high-reward investments on their behalf. [16] The typical fund will invest in a portfolio of 10-20 startups. Investments are typically made over the first 5 years of the life of the fund. Returns from these investments are realized during years 5-10, through an "exit," that is, when a portfolio company is either acquired by another firm or issues it shares on a public market through an initial public offering (IPO). The capital invested by the limited partners is typically illiquid until a portfolio company exits.

The 10-20 investments are made with the expectation that only one or two will succeed. Most are expected to fail, and a few investments will break even. From the LP perspective, these one or two successes must be sufficient to make up for the investments in all of the failed companies, in addition to returning a premium for the length and illiquidity of the investment. The venture capital fund (run by GPs) typically is entitled to keep $20 \%$ of the proceeds of a sale, but only after the invested capital has been returned. The nature of the venture capital investment strategy implies that the most successful venture-backed businesses will be easily scalable and in high-growth markets in order to provide large payoffs within a short time frame. 17] Thus, venture capital investors are incentivized to pick companies that have the potential to return 10 to 100 times the amount invested within three to five years of the investment.

Venture capital funds may invest at multiple stages of a company's develop- 
ment, starting with early "seed" rounds, typically $\$ 1$ million or less, continuing through subsequent rounds (named "A", "B", etc.) typically on the order of $\$ 10$ million, and in late-stage growth rounds that can raise $\$ 10-\$ 100$ million or more. The amount invested varies depending on the size of the fund and the needs of the company. Several venture capital firms often invest in a given round as a syndicate to further diversify risk, and a given company may be financed by different funds in each round.

\section{Methodology}

An assessment of the performance of cleantech companies from the perspective of $\mathrm{VC}$ investors and relative to companies from other sectors can inform judgments about whether the cleantech sector is well-suited to the VC investment model. To this end, we compiled a database of all early-stage venture capital investments in cleantech as well as in two other technology sectors. Previous studies have discussed the changes in the amount of early-stage cleantech investment during the period of increased investment and just after the retrenchment began; this study is the first one to study the entire boom and bust cycle of early-stage cleantech investments from 2006-2011.[18, 19] In order to report the performance of those investments, we have selected A-Round investments made during that time period (Figure 1). This data enabled us to compare the risk and return profiles of cleantech investments against those of other sectors. Moreover, we used the database to isolate commonalities among companies that underperformed as $\mathrm{VC}$ investments and to identify factors that drove success in other sectors but not in cleantech.

We evaluate the performance of cleantech venture capital investment over the life of the investment as of January, 2015, starting with the A-round financing event and concluding when the invested company either closes or returns capital to the investors. Previous analyses of non-sector-specific venture investment have evaluated the performance of investment funds using proprietary data provided by investors in the funds. $[20,16,21,22]$ This study addresses the 
need for transparent analysis based on publicly available data. Because cleantech investments were made by both sector-targeted funds and generalist funds, we use individual financing events and track the returns to investors.

\subsection{Sector Analysis}

We compare the performance of cleantech investments to that of software and medical technology investments. Software companies include those producing enterprise and consumer focused software, web applications, mobile applications, and social media. Medical technology companies include those commercializing pharmaceuticals and medical devices.

We have also subdivided the cleantech sector according to the type of innovation the company was commercializing. Categories were selected so that companies with similar capital requirements and length of expected development times could be compared. These five categories were, in order beginning with the most capital intensive and longest development cycle

- Materials, chemicals, or manufacturing processes

- Hardware integration

- Software or software appliances

- Finance and deployment

- Other products or services, including recycling, consulting, and energy efficiency audits

We placed each cleantech company into only one of five categories based on the most capital-intensive innovation it commercialized during its early stage when it raised VC funding. In the event that a company fell into more than one category, it was classified into the most capital-intensive category.

Companies categorized as developing new materials, chemicals, or manufacturing processes included those that used discoveries in materials science or chemical or biological engineering to create new materials or chemicals that 
could be used to generate, convert, or store energy. Energy generation materials included new collector materials for solar photovoltaics, such as copper-indiumgallium-selenide. Energy storage materials included components of new batteries. For example, novel cathode materials such as nickel-manganese-cobalt-oxide for better performance in lithium-ion batteries. The category also includes biofuels companies creating fossil-fuel replacements from plant matter. Finally, the category includes companies developing a new manufacturing process for creating previously-known compounds, such as using algae to create ethanol.

Companies that were classified as hardware integrators included those that sold a tangible product, but where that product was manufactured by combining already existing technologies. Companies in this category faced engineering challenges in integrating parts for the first time, but the science and manufacturing behind the component technologies was well proven. This category included companies developing electric automobiles, vehicle charging infrastructure, and other transportation equipment. As a result, the technical risks faced by these companies was generally lower than the technical risks of companies in the previous category. However, because of their scale and relative novelty, they were often unable to take advantage of contract manufacturing capacity or established supply chains. One such company, Better Place, hoped to assemble electric cars and electric vehicle charging stations.

Companies in the cleantech software category often developed and sold software to electricity consumers (sometimes via the utilities) to help monitor and manage local usage and promote energy savings. Other software providers created products that would help utilities or micro-grid operators automatically manage and control loads on the grid. Companies that sold a packaged combination of software-enabled hardware were categorized as software appliances companies. These differed from purely software companies because they required integrated hardware that is sold by the company, whereas pure software products were sold independently. Furthermore, these differed from the hardware companies described above because the key innovation was contained in the software control system. 
Table 1: Financing events in the data set. The table shows the number of companies in the data set in each technology sector, as well as the breakdown of companies with disclosed A-round financing events. Each subsequent row reports the number of "live" companies remaining after we filtered the data set, first to limit our scope to companies that received A-round financing events between 2006-2011, then to companies whose exit outcome is known or reasonably guessed. The details of this filtering process are described in Section 3.2

\begin{tabular}{rccc} 
& Cleantech & Software & Medical \\
\hline All Companies & 1611 & 25635 & 4174 \\
\hline All A-Rounds & 365 & 6033 & 982 \\
A-Round 2006-2011 & 266 & 3064 & 523 \\
Included in Set & 185 & 2169 & 260
\end{tabular}

Companies categorized as finance or deployment firms typically served as project developers for well-test technologies such as solar photovoltaic or wind energy or provided capital to project developers. While project development may be capital intensive, these projects are most often funded by debt, not by equity finance from venture capital. Some companies in this category provided loans for homeowners and commercial customers to install new technology.

Finally, other companies, those that did not fit into the previous categories often provided services. These included companies that offered materials recycling services, access to recycling infrastructure, energy audits, or energy efficiency consulting programs. These companies were not dependent on substantial technology risk and tend to be relatively capital efficient.

\subsection{Venture Capital Investment Data}

In order to evaluate the cleantech financing boom that peaked in 2008 and subsequent bust, we evaluate financing rounds that occurred from 2006 to 2011 and exits through the end of 2014. To investigate the performance of individual firms, company-specific financing data for each round of financing was obtained from CrunchBase. 23.

Data on the market capitalization of companies during an initial public offering were obtained from NASDAQ. In order to benchmark the performance 
of the VC investments, returns were compared to historical data from the S\&P 500 via the Federal Reserve Bank in St. Louis and Yahoo! Finance.

The details of financing events and exits are sometimes unavailable to the public. Our analysis focuses therefore on the set of companies in the CrunchBase database. Changes in round-by-round financing in each industrial sector (software, medical technology, and cleantech) indicates that no systematic differences in the availability or quality of data exists across the three categories.

Occasionally, the amounts invested in early funding rounds are not public. We find that undisclosed fundraising events are more common in initial financing rounds and earlier funding years and have become less frequent - these trends are consistent across sectors. Across all the three sectors approximately $23 \%$ of startups had disclosed A-rounds. When an A-round financing event was disclosed but the amount of money raised in the round was not available, we approximated the funding by using the median level of all disclosed A-round funding events in that sector, and we set uncertainty bounds at the first and third quartile.

Acquisition prices are also not always available, because there is no disclosure requirement unless the acquisition is material to a publicly traded acquirer's business. Undisclosed exits are often an indication that an investment did not return capital to investors. For these companies, we estimate on average that the exit returned the invested capital to investors, yielding a $1 \times$ multiple, and we set our uncertainty bounds at $0 \times$ and $2 \times$. Companies that closed or declared bankruptcy are categorized as having failed, and are recorded as having an exit value of $\$ 0.0$. To separate companies that "succeeded" from companies that "failed," we use a very conservative metric, classifying "successful" companies as those who returned more capital to A-round investors than what they originally invested. Because VC investors have a higher threshold for success, this classification will conservatively classify more companies as successes, our results should slightly overestimate the performance of cleantech investments.

Our data shows that ninety percent of companies that received venture capital investment during this period neither exited nor closed. Their status as 
successes or failures can be difficult to categorize. Some of these companies may be growing steadily and may raise new funds. Other companies may yet exit. Still others will continue to operate for many years without exiting. Companies in this last category are considered failures from the perspective of the investors, who expect a large exit within three to five years. Investors refer to them as the "living dead" or "zombie" companies. 24, 25, 26, 27] Among these companies that have not exited or closed, we separate them into "dead" companies, and "live" companies. Over $80 \%$ of the companies that either exit or raise a new round of funding do so within three years of their previous funding round. Therefore, companies that received venture capital investment in the past three years are categorized as "live" companies, and are excluded from the data set, since their fate cannot yet be determined. It is likely that on average, "live" software and medical technology companies would fare approximately as well as companies who received investment earlier and whose fate has been determined. It is possible that because the cleantech sector is newer, recent investments may perform better than the initial cohort of investments. This may be true in particular if current live companies have adapted to changing conditions after the first wave of failures. For instance, they may have different business models or they may have access to support services of local governments, incubators, and accelerators that were not available to the first cohort.

Those companies that have neither exited nor raised new funds in the past three years are considered "dead" and we record them as having an exit value of $\$ 0$. The number of companies remaining in each sector - those that had disclosed fundraising rounds between 2006 and 2011 and are not "live" companies can be found in Table 1

\subsection{Assessment of Risk and Return in Venture Capital Portfolios}

When comparing the performance of investments we average the investments in each category in each year in an effort to reduce the effect of the well-known high variability in venture capital returns. 28. An individual VC investor will often make only one or two investment per year; therefore we aggregate all 
Table 2: Example investments and returns. The distribution, IRR, and cash-on-cash multiple for an investment of $\$ 10$ million and a $\$ 200$ million exit are shown as a function of the ownership stake at exit. All dollar values are reported in millions.

\begin{tabular}{lc|lc|ccc|ccc|ccc}
\multicolumn{2}{c}{ Investment } & \multicolumn{3}{c}{ Exit } & \multicolumn{3}{c}{$8 \%$ Stake } & \multicolumn{3}{c}{$12 \%$ Stake } & \multicolumn{2}{c}{$16 \%$ Stake } \\
Date & $V_{\text {PIC }}$ & Date & $V_{\text {exit }}$ & Dist. & IRR & CoC & Dist. & IRR & CoC & Dist. & IRR & CoC \\
& $(\$)$ & & $(\$)$ & $(\$)$ & $(\%)$ & & $(\$)$ & $(\%)$ & & $(\$)$ & $(\%)$ \\
\hline $01 / 01 / 08$ & $\$ 10$ & $01 / 01 / 11$ & $\$ 200$ & $\$ 16$ & 16.9 & 1.6 & $\$ 24$ & 33.9 & 2.4 & $\$ 32$ & 47.3 & 3.2 \\
$01 / 01 / 08$ & $\$ 10$ & $01 / 01 / 13$ & $\$ 200$ & $\$ 16$ & 9.8 & 1.6 & $\$ 24$ & 19.1 & 2.4 & $\$ 32$ & 26.2 & 3.2
\end{tabular}

Table 3: 2006 cleantech A-round investments. The outcome, distribution, IRR, and cash-oncash multiple for each investment and for the yearly portfolio of investments are shown. All dollar values are reported in millions.

\begin{tabular}{|c|c|c|c|c|c|c|c|}
\hline \multicolumn{3}{|c|}{ Investment } & \multicolumn{3}{|c|}{ Exit } & \multirow[b]{2}{*}{ IRR } & \multirow[b]{2}{*}{ Multiple } \\
\hline Date & $\mathrm{V}_{\mathrm{PIC}}$ & Outcome & Date & $\mathrm{V}_{\text {exit }}$ & Distribution & & \\
\hline $01 / 18 / 06$ & $\$ 2.9$ & & & & & & \\
\hline 07/01/06 & $\$ 25.0$ & Closed & & & & & \\
\hline $07 / 31 / 06$ & $\$ 15.0$ & Bankruptcy & & & & & \\
\hline 08/01/06 & $\$ 2.9$ & Acq. - Undisc & $12 / 01 / 10$ & $\$ 23.8$ & $\$ 2.9$ & $0 \%$ & 1.00 \\
\hline 09/18/06 & $\$ 4.0$ & & & & & & \\
\hline $10 / 12 / 06$ & $\$ 20.0$ & IPO & $04 / 21 / 14$ & $\$ 687.7$ & $\$ 82.5$ & $21 \%$ & 4.13 \\
\hline $10 / 16 / 06$ & $\$ 7.0$ & Acq. - Undisc & $10 / 08 / 10$ & $\$ 58.3$ & $\$ 7.0$ & $0 \%$ & 1.00 \\
\hline $11 / 1 / 06$ & $\$ 5.2$ & Closed & & & & & \\
\hline $11 / 1 / 06$ & $\$ 8.0$ & & & & & & \\
\hline $11 / 10 / 06$ & $\$ 0.6$ & Acquired & $04 / 15 / 11$ & $\$ 17.0$ & $\$ 2.0$ & $34 \%$ & 3.61 \\
\hline Portfolio & $\$ 90.5$ & $\begin{array}{l}\text { Failure Rate } \\
\qquad 80 \%\end{array}$ & & $\$ 786.8$ & $\$ 94.4$ & $0.6 \%$ & 1.04 \\
\hline
\end{tabular}


the deals in a given sector in a given year to measure the investor's expected outcomes. Table 3 shows the cleantech investments of 2006 to illustrate our methodology. This approach includes both the best and worst outcomes for investors. Other studies have shown that the best outcomes for venture capital accrue to the top quintile of funds. 20] Therefore, we have also compared performance for only the best investments in each sector.

We evaluate the risk of investment in each of the three sectors by comparing the historical failure rates. For each investment year, we calculate the fraction of companies that failed to reach a successful exit. For instance, in 2006, two of ten cleantech A-round investments returned at least the invested capital to investors (see Table 3). This is recorded as an $80 \%$ chance of failure for A-round cleantech investments in that year. Recall that the venture capital investor typically expects an $80 \%-90 \%$ failure rate in early rounds.

Risks that investors take must be matched by returns from successful investments. There are many ways to evaluate the return of an investment. Because we are interested in comparing the performance across the three sectors, we report the internal rate of return (IRR) and a cash-on-cash multiple (CoC). These metrics are compared for two hypothetical investments in Table 2 .

The returns to investors depend upon the amount invested (the paid-incapital) $V_{\text {PIC }}$, the total enterprise value at the time of exit $V_{\text {exit }}$, the ownership stake at exit $f_{\text {stake }}$, and the elapsed time until returns are realized $t$.

For companies that are acquired, the exit value is simply the sale price. For companies that exit through an IPO, the total exit value used here is the market capitalization based on the price at which the initial shares are offered. It is important to note that there is often a "lockup" period during which early investors and founders cannot liquidate their position (realize a return). This period often lasts 180 days after the IPO. During this period, the publicly traded stock may appreciate or depreciate.

The returns distributed to investors depend upon the number of shares they own at the time of exit. This fractional ownership stake depends on the terms of the original financing deal, as well as subsequent investments. The stake an 
investor takes during a fundraising event varies with each deal, and this stake is usually diluted when new shares are issued in subsequent fundraising rounds. Though there are no fixed ranges, when a company exits an A-round investor may own $5-50 \%$ of the company (though $<15 \%$ is typical). Because the exact ownership stakes are often not disclosed until a company files for an IPO, our calculations model the returns assuming an estimated stake of $12 \%$, with our error bounds set at $8 \%$ and $16 \%$. This central value and associated uncertainty bounds were derived from numerous publicly disclosed investments in startups across the three sectors. The effects of ownership stake on IRR and multiple can be seen in Table 2 .

In our analysis, we discount for time from the perspective of the limited partners 17 The LP typically does not pay in capital until the investment is made. Therefore, the time of the investment is the time between the funding event and the exit. Table 2 evaluates the returns from two hypothetical investments that are identical except for the amount of time between investment and exit. As discussed below, time will affect IRR but not the cash-on-cash multiple.

\subsubsection{Internal rate of return}

The IRR for a given investment accounts for the time elapsed $(t)$ between the investment and the exit. IRR is the value of the discount rate $r$ at which the net present value of an investment equals zero. IRR can be used by an investor to compare investment alternatives, and indeed is often reported by venture capital funds. 20. In general, a higher IRR indicates a better investment, though we note that there are many caveats to using IRR as the only measure of performance and that it may not always lead to a straightforward comparison. 30.

\footnotetext{
${ }^{1}$ In this paper we consider the investment returns exclusive of fees collected by the VC fund. These fees are often structured as an annual operation fee of $2 \%$ of the committed capital, which may decrease towards the end of the 10-year life of the fund, and $20 \%$ of the proceeds of all earnings after the limited partners paid-in-capital has been returned. See, for instance, Ref. 29]
} 
For a single investment the IRR, $R$, is given by the expression:

$$
R=\left(\frac{V_{\text {exit }} f_{\text {stake }}}{V_{\text {PIC }}}\right)^{1 / t}-1
$$

For a portfolio of $n$ investments, $R$ is given by the solution to the equation

$$
0=\sum_{n} \frac{V_{\text {exit }^{n} f_{\text {stake }}}^{n}}{(1+R)^{t^{n}}}-\sum_{n} V_{\mathrm{PIC}^{n}} .
$$

\subsubsection{Cash-on-cash multiple}

The cash-on-cash multiple $\left(m_{\mathrm{CoC}}\right)$ provides a way to compare investments without considering the time of the investment. This metric is also often used by venture capital funds when they report their performance. The multiple is determined according to the expression

$$
m_{\mathrm{CoC}}=\frac{V_{\text {exit }}}{V_{\text {PIC }}} f_{\text {stake }} .
$$

For a portfolio of $n$ investments, the total cash-on-cash return $M_{\mathrm{CoC}}$ is determined by a sum of the capital distributed divided by the capital invested, according to

$$
M_{\mathrm{CoC}}=\frac{\sum_{n} V_{\text {exit }^{n}} f_{\text {stake }^{n}}}{\sum_{n} V_{\mathrm{PIC}^{n}}} .
$$

\subsubsection{Expected multiple for successes}

We also evaluate each investment year according to the expected return multiple on successful investments. This calculation is identical to the cash-oncash computation in Equation 4, except that it is summed across only successful investments.

\section{Results}

\subsection{Cleantech Investment Risk and Reward}

\subsubsection{Risk for Early-Stage Investors}

The failure rates of venture capital A-round investments in cleantech, software, and medical technologies, defined as the percentage of companies each year that failed to at least return invested capital (a $1 \times$ return), are shown in 

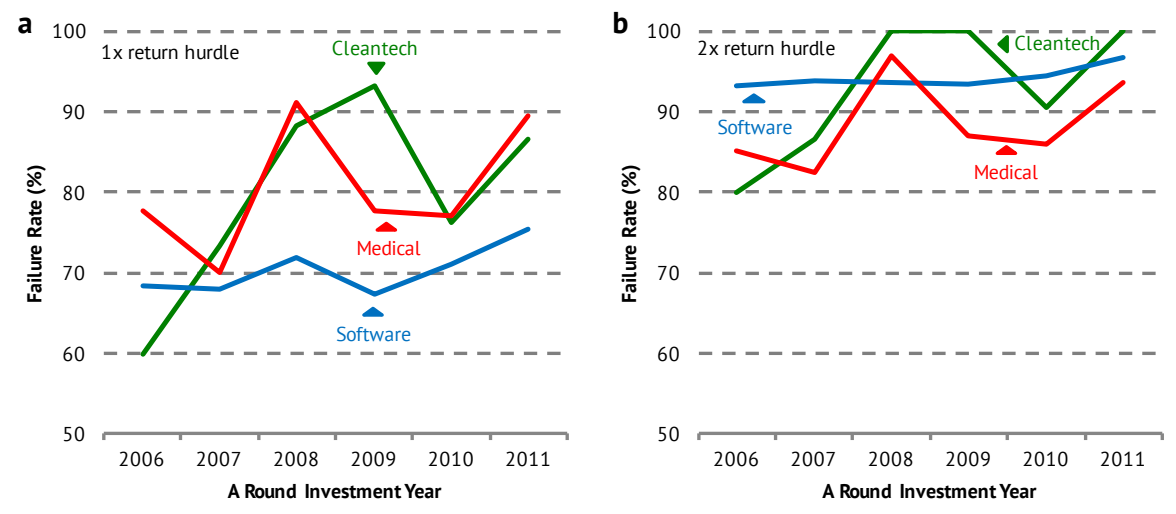

Figure 2: Investment failure rate for A-round venture capital investments. For each investment year, the percentage of investments that failed to return $1 \mathrm{x}$ capital to investors is shown in part (a), and the percentage that failed to return $2 \mathrm{x}$ the capital in part (b). Cleantech investments (green) are compared to software (blue) and medical technologies (red).

Figure $2 \mathrm{a}$. Cleantech investments were approximately as likely to fail as investments in medical technologies, but compared to those in software companies failed more often and were more variable. Software A-round investments failed approximately $70 \%-75 \%$ of the time, whereas cleantech and medical technology investments often failed more than $75 \%$ of the time.

When the metric for success is more strict, that is, if a company must at least double the invested capital, the failure rates are higher, and considerably so for cleantech (Figure 2p). Under this requirement, medical technologies failed least often, whereas software companies failed at a consistent $90 \%-95 \%$ rate, in line with VC expectations for early-stage companies. After 2007, cleantech companies failed more than 90\% of the time, and notably, in 2008, 2009 and 2011, none of the companies receiving A-round investments surpassed this hurdle.

\subsubsection{Returns by Investment Sector}

Figure 3 shows the returns to investors for A-round investors across the three sectors we considered. The cash-on-cash returns for all successful companies (those that beat the $1 \times$ hurdle rate) for each year of investment are shown in Figure 3a. In 2006 and 2007, when cleantech companies succeeded, they 

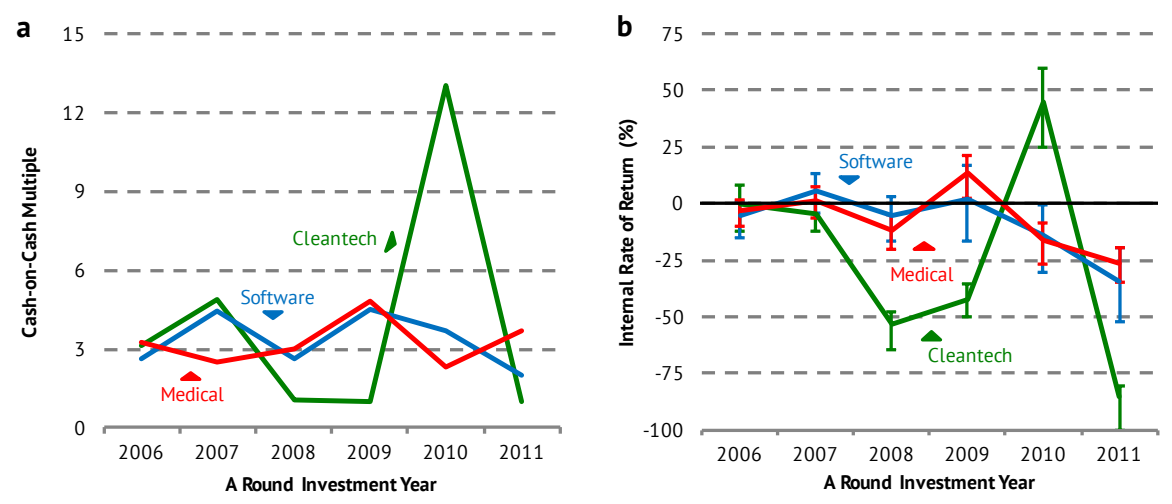

Figure 3: Returns to investors by industry sector in A-round investments. Returns are shown as measured by (a) cash-on-cash multiples for successes and (b) internal rate of return for all investments. Cleantech investments (green) are compared with software technology investments (blue) and medical technology investments (red).

yielded investor returns at scales comparable with those of other sectors. The peak of cleantech investment activity in 2008, however, signaled the end of good cleantech performance, with the notable exception of 2010. The 2010 cleantech returns are dominated by Nest Labs, a company selling software-enabled smart thermostats, which was acquired by Google in 2014 for $\$ 3.2$ billion.

The calculated IRR for all companies in each investment year is shown in Figure 3p. Because the IRR calculation evaluates both successes and failures, the high failure rate of cleantech becomes apparent. Every year after 2006again with the exception of the 2010 Nest investment - cleantech yielded negative returns (investors lost money) and performed much worse than the other sectors.

\subsubsection{Risk and Return}

As discussed in previous sections, the returns to investors when investments succeed must be great enough to overcome the failed investments. The returns must also provide an additional premium for the length of time the capital is illiquid, the high risk, and the fees charged by the VC investor. Figure 4 compares the risk and return of each investment year across the three different 


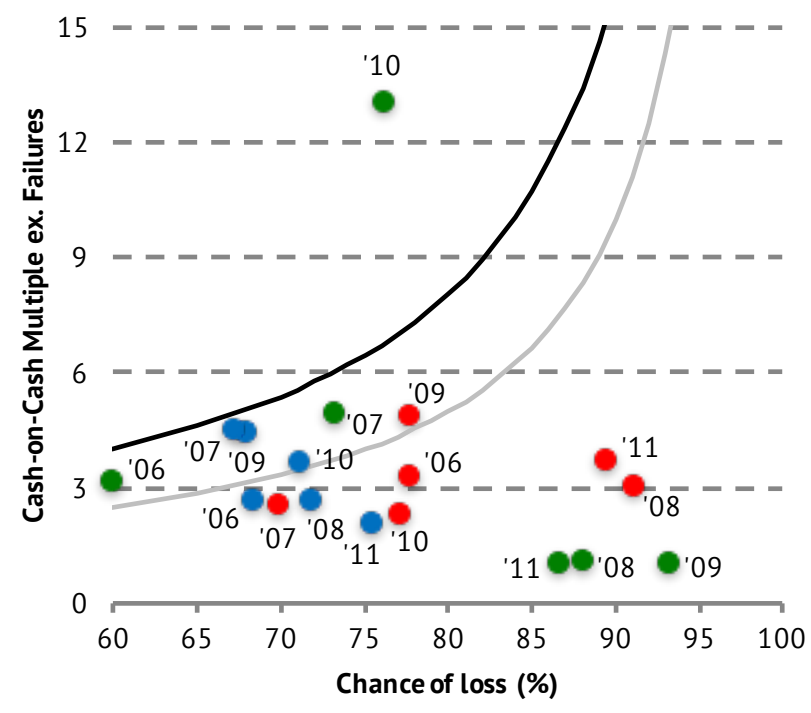

Figure 4: Risk and return for VC investments in in cleantech (green), software (blue), and medical (red). The returns to investors for A-round investments that at least returned invested capital are plotted against the historical failure rate and compared with hypothetical returns in a break-even scenario (light gray line) and from investing in public markets (black line). 
technology sectors. For each investment year, the cash-on-cash multiples for investments that at least returned invested capital are shown against the risk of loss. Riskier investment portfolios require a higher return to beat other investment scenarios. In this case, the risk and return are compared to a breakeven scenario (light gray line), where invested capital is returned dollar-fordollar, without discounting for time, and a public market benchmark (black line). For our benchmark we use an investment made in the S\&P 500 index in January 2006 and held until January 2015. This investment would have yielded a $5.4 \%$ annual return.

With a few exceptions, investments in each sector tended to cluster together. Software investments offered the highest returns and a risk profile in line with VC expectations. Medical technologies, by contrast, were slightly more risky and had greater variability in risk from year to year, but offered returns in the same range. After 2007, cleantech offered high-risk investments and low returns, with the notable exception of 2010, as discussed in the previous section.

We note that across all three sectors, investment bundles in most years failed to beat the public market, and many failed to break even. First, this is a result of the early stage and high risk of investing. VCs will invest more money into the most promising companies in subsequent financing rounds, increasing their ownership stakes and improving overall performance. Second, this analysis includes all companies that received investment, supporting the findings of Mulcahy that only the top venture capital funds yield consistently strong returns. 20.

To evaluate how the cleantech sector would have performed for only the best investors, we have also considered the case where an all-knowing investor selected only the best companies, defined as the ten most valuable companies in each sector at the time of exit. As shown in Figure 5 this risk-free portfolio would have earned an $11.6 \times$ return on software investments. Cleantech investments, which would have returned $8.6 \times$ the original investment, would have outperformed medical technologies, which returned $4.2 \times$. However, because the winning medical technology exits were larger than those in cleantech, and be- 
cause the compensation structure of most VC partnerships rewards bigger exits, the GPs would have earned approximately $20 \%$ more by investing in medical technology, even though their LPs would earn less.

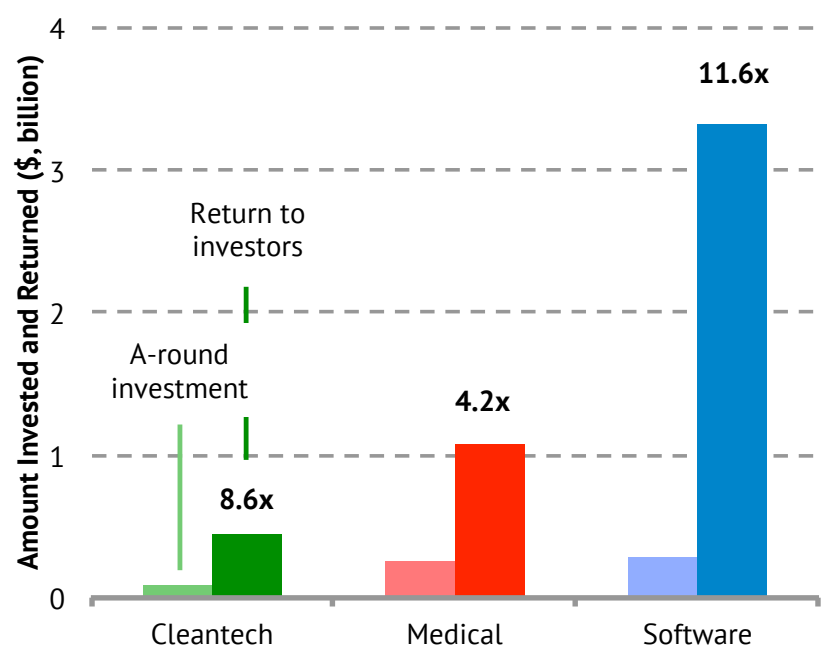

Figure 5: The amount invested by and returned to A-Round investors for an ideal investment portfolio, where A-round investments were made only in the 10 largest exits in each technology sector. The cash-on-cash multiple for each of these portfolios is also shown.

\subsubsection{Exit Outcomes}

Figure 6] compares frequency of both types of exit event - IPO or acquisitionfor each sector. In 2010, it was observed that there had been few acquisitions in the sector and there was evidence that VC investors as a class would be less likely to invest when exit opportunities were rare.[18, 31] Our data shows that this trend persisted through the lifetime of those investments. Software companies were the most likely to exit. Cleantech companies were less likely to exit overall, (as was shown in Figure 2 ) but were approximately as likely to go public as medical technology companies. Only about $3.8 \%$ of cleantech companies were acquired, compared with $6.3 \%$ of medical technology companies and $11.9 \%$ of software companies. 


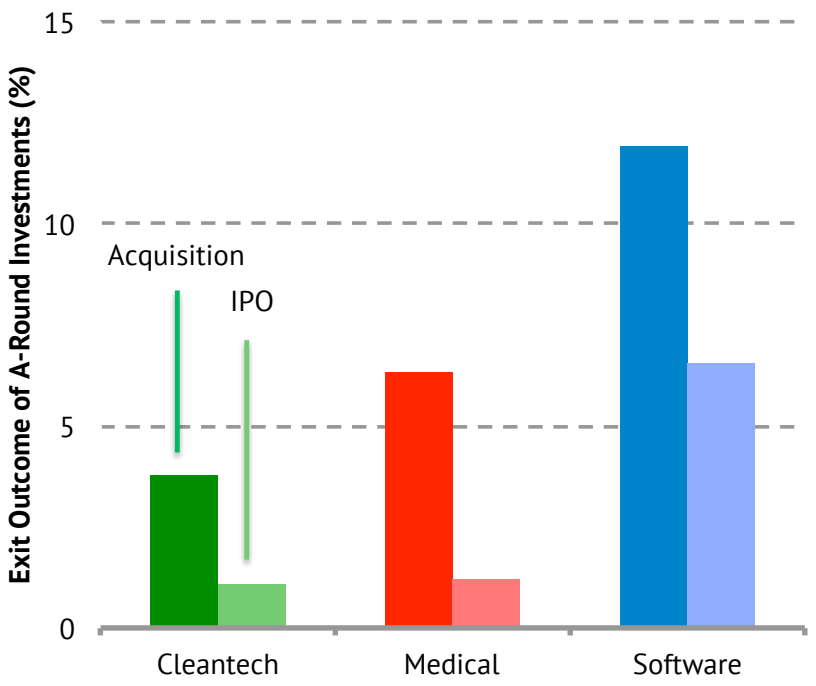

Figure 6: The exit outcomes are shown as the percentage of companies receiving A-round in each sector (cleantech, medical technology, and software) that exited through an IPO or acquisition. Cleantech companies exited less often and were less likely to find an acquirer.

\subsection{Cleantech Sub-sector Performance}

The underperfomance of cleantech investments was driven by large investments and poor performance in "deep technology" innovations: Materials, Chemicals, and Processes, and Hardware Integration, as shown in Figure 7. A-round investments in Materials, Chemicals, and Processes lost approximately $\$ 5$ for every $\$ 6$ invested, yielding a loss of nearly $\$ 650$ million. Hardware investments performed even more poorly, returning only $\$ 30$ million on investment of nearly $\$ 600$ million. Companies commercializing clean energy deployment business models and companies commercializing other clean energy technologies also failed to return invested capital, posting multiple of $0.26 \times$ and $0.21 \times$, respectively.

The software and software appliance category was the only class of investment that rewarded investors. These investments returned nearly $\$ 550$ million on investment of just over $\$ 150$ million, a $3.7 \times$ multiple. Without the Nest investment, cleantech software would have yielded lower returns, but it would 
still have returned more than the invested capital. In part, this may reflect the suitability of the venture capital model for software.

Investors responded to the performance of these subsectors by changing their investment strategies. As shown in Figure 8, investments in materials and hardware have declined over the past decade, and have been replaced by investments in software and software appliances.

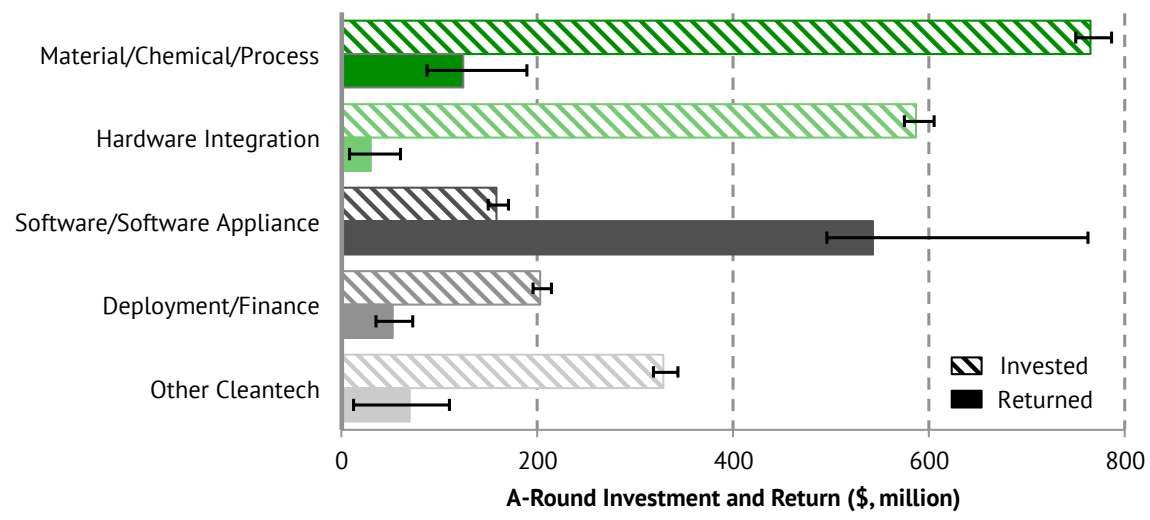

Figure 7: The amount invested (striped bars) and returned (solid bars) to A-round investors in each subcategory of clean energy technologies shows that underperformance was driven by large investments and poor returns by materials and hardware investments.

\section{Discussion}

The cleantech boom-and-bust demonstrated that cleantech investments are poorly suited to the VC investment model for four reasons. First, the investments were illiquid because the development of new materials and hardware takes longer than the 3-5 years VCs expect. 32. Second, they required significant capital, using hundreds of millions of dollars of $\mathrm{VC}$ investment to build and scale factories, in many cases even before the fundamental technology development was complete. 33] Third, these companies often sold into commodity markets, where margins are thin and the pressure to scale is immense. 34, 18, Finally, the utilities and large industrial corporations that were seen as likely 


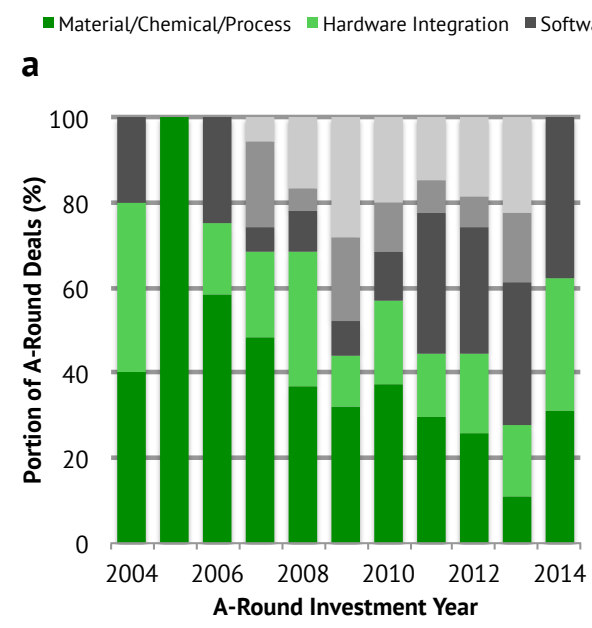

b

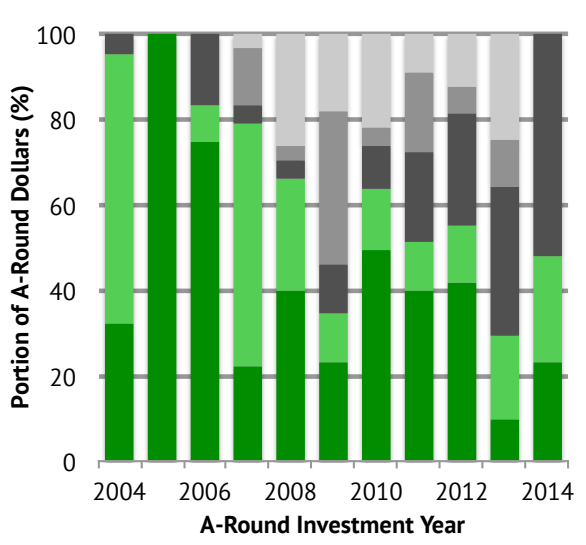

Figure 8: The proportion of investment activity (a) and investment amounts (b) in each cleantech subsector from 2004-2014. Investment in companies commercializing new materials (dark green) and hardware (light green) has decreased and largely been replaced by investments in software (dark gray).

acquirers of these startups were reluctant to buy risky startups, valuing them based on their profitability rather than their potential for growth. [18, 31] These four factors conspired to make VC cleantech investments an expensive experiment, where hundreds of millions of dollars were needed before the success of the company could be determined. Based on our results, the recent VC capital flight away from cleantech hardware and materials companies is rational and unlikely to reverse, because alternative sectors are more lucrative to VCs.

Unlike medical and software technology sectors, cleantech may require a more diverse set of actors and innovation models.

To succeed, future cleantech start-ups will need to seek a broader set of funding sources than just VC, and should wait longer before raising VC money. In the interim, they can reduce capital expenditures by using shared or leased resources at universities, research institutes, or incubators. And they can leverage federal and state grants to advance technology development before raising substantial funding and starting the countdown to investor return expectations. 
Still, these start-ups cannot improve their prospects alone; large companies will have to play a crucial role in innovation and commercialization, as they do in other sectors. Established software and medical companies are more willing to acquire risky startups, and they are willing to set the price as a multiple of the startups' growth, whereas the likely cleantech acquirers - utilities and industrial corporations - tend to be more risk-averse and value startups based on profits instead of growth. Unless corporate behavior in the cleantech sector shifts to resemble that in other sectors, cleantech start-ups will lack lucrative exits.

Finally, in addition to corporations, other non-VC investors will need to invest in cleantech innovation in order to enable different results from the bleak performance over the past decade. In particular, investors with substantial capital to allocate and longer time horizons to realize returns could match up much better with the return profile of a diversified portfolio of cleantech startups. Such investors could include pension funds, sovereign wealth funds, family offices, and other institutional investors, as well as philanthropies, foundations, and other charitable organizations.

\section{Limitations and Further Research}

Our research provides context to the cleantech boom and bust from 20062011 when venture capital investment in the sector grew and subsequently contracted. In the years since, there has been some recovery of private funding support for early-stage companies. This renewed interest, however, has not been sufficiently allocated to companies developing breakthrough energy technologies. By evaluating the publicly available data on investment and returns during this period, we were able to compare the performance of the cleantech sector to the software and medical technology sectors. Our results provide several possible explanations for the change in investor behavior. Our research is an early investigation in this space and subject to limitations which can provide a basis for ongoing discovery and future research.

First, our study is based on publicly available financing data for private 
companies. Because these companies and their investors are rarely obligated to report details of financing, it can be difficult to estimate the extent to which data is not included in the set. Our analysis indicates that there is no systematic difference between the level of data accuracy and completeness between the three sectors compared (cleantech, software, and medical technology) but future research combining additional public or private data sets may provide additional useful analysis.

Second, our data set includes exits through the end of 2014, and our study focuses only on the investment returns for investments made from 2006 to 2011. Our results show that through 2014, investor behavior changed to favor investment in software and software-appliance over materials, chemicals, and hardware. It would be valuable for future research to evaluate whether this trend continued in 2015 and 2016. Further, this change in investor behavior may have lead to better (or worse) investment results for investments made after 2011.

Third, there is an inherent limitation to separating external market effects from the nature of the investments themselves. These external factors, highlighted in Section 2.1. included the credit crunch and financial turbulence of 2008 and a glut of solar panels made in china. 35. We do not attempt to predict what the returns may have been if these events had not occurred. Future research using case studies of successful and unsuccessful firms may be able to separate the effects of these external events from internal limitations to the venture capital funding model.

Finally, we note that this study is limited to evaluating companies that raised venture capital. There are numerous other funding sources for earlystage companies and some of these may be more suitable for capital-intensive and slow-growing cleantech companies. Future research on the prevalence of alternative and emerging financing models for these companies would enhance the body of knowledge in this emerging area of research. 


\section{Conclusion and Policy Implications}

Our analysis of the publicly available data shows that early-stage investment in clean energy technologies from 2006-2011 underperformed compared to investments in other sectors.

The set of investments in clean energy technologies studied here were riskier than investments in other sectors and offered lower returns. Cleantech companies were less likely to be acquired or exit through an IPO. Over $90 \%$ of cleantech A-round investment failed to return substantial capital to investors each year after 2007. When cleantech investments did succeed, the returns were lower than investments in other sectors as measured by both cash-on-cash multiples and IRR. These successes failed to compensate for the increased risk in the sector. Even when considering only the best investments - those with the largest exits - VC investors would prefer to invest in software and medical technologies before cleantech.

Cleantech underperformance was driven by the poor performance of investments in deep technology innovations. In particular, A-round investments in new materials, chemicals, and processes, along with investments in hardware integration companies, lost nearly $\$ 1.25$ billion. Investor behavior responded to this underperformance by shifting cleantech investments to software and software appliances, which are both less capital-intensive and offer greater opportunities for growth.

Commercializing new clean energy innovations will require support from the public sector that can then attract investment from large corporations and patient investors. To provide this support, the United States and 19 other nations should fulfill their Mission Innovation pledge to double support for advanced energy R\&D. These governments should also increase support for commercialization of this research through networks of incubators and accelerators.

Public policy provides a lever to encourage participation in cleantech innovation, both from corporations and from institutional investors. First, policymakers should increase support to start-ups and private investors to pro- 
vide an alternative to VC funding. The Department of Energy can do this by increasing funding for the Small Business Innovation Research and Small Business Investment Company programs and supporting the expansion of private and non-profit cleantech incubators and accelerators. Second, the federal government should further expand access to federal research institutes through programs like the Department of Energy's Small Business Vouchers. Third, to encourage corporations to participate in cleantech innovation, the federal government should incentivize regional partnerships between large corporations, startups, and incubators, and offer favorable technology transfer terms from the national laboratories. Fourth, the government should continue to develop a national manufacturing program by continuing to fund the National Network of Manufacturing Institutes that start-ups and large companies alike can access to improve manufacturing techniques en route to new technology commercialization. Finally, the Department of Energy should support entrepreneurship at the national laboratories by building on the success of the Cyclotron Road program currently hosted at Lawrence Berkeley National Laboratory and now expanded to Argonne and Oak Ridge National Laboratories.

If fulfilled, these policy recommendations can support the right environment to attract a diverse mix of players to invest in innovation. They would also enable entrepreneurs to develop their technologies, for example by using shared public resources, without requiring $\mathrm{VC}$ funding.

Finally, these recommendations could dovetail with recent announcements from the private sector, notably the Breakthrough Energy Coalition's commitment to support clean energy innovation. This Coalition has pledged to identify promising start-ups and technologies in which to invest multiple billions of dollars of "patient" capital that will not require returns for a decade or more. They also plan to attract follow-on capital from institutional investors. The public sector and academic institutions can assist these investors by providing independent, third-party technical evaluations. The investors will need to work closely with the regional and national networks of laboratories, incubators, and accelerators to help support their investments through the phases of technology 
and business development over the course of several years.

\section{Acknowledgments}

The authors are grateful to David Danielson, Reuben Sarkar, Eli Levine, Jennifer Garson, Erik Birkerts, Paul Seidler, Alex Foucault, Johanna Wolfson, Teryn Norris, Sabrina Howell, Melissa Lott, Tonio Buonassisi, Ilan Gur, John MacWilliams, Rob Writz, Stephen Lacey, Shayle Kann, Kenneth Alston, Rob Day, Ashley Grosh, Veery Maxwell, Rich Hossfeld, Alex Payne, Joshua Posamentier, Greg Mulholland, John Balbach, and Tom Burton for helpful discussions and comments. The authors also acknowledge the support of the U.S. Department of Energy and the American Association for the Advancement of Science (AAAS) Science \& Technology Policy Fellowship for support that led to the undertaking of this study.

\section{References}

[1] K. Caldeira, A. K. Jain, M. I. Hoffert, Climate sensitivity uncertainty and the need for energy without CO2 emission., Science (New York, N.Y.) 299 (5615) (2003) 2052-4. doi:10.1126/science.1078938

URL http://science.sciencemag.org.prox.lib.ncsu.edu/content/ 299/5615/2052.abstract

[2] Adoption of the Paris Agreement, Tech. rep., United Nations Framework Convention on Climate Change, Paris (2015).

URL http://unfccc.int/resource/docs/2015/cop21/eng/109r01.pdf

[3] International Energy Agency, Energy Technology Perspectives (Executive Summary), Tech. rep., International Energy Agency (2014). doi:10.1787/ energy\{\_\}tech-2014-en.

[4] M. L. Rorke, H. C. Livesay, D. S. Lux, From invention to innovation : commercialization of new technology by independent and small business inventors., Tech. rep., U.S. Department of Energy, [Washington DC] (1989). 
[5] C. Frank, C. Sink, L. Mynatt, R. Rogers, A. Rappazzo, Surviving the valley of death: A comparative analysis, The Journal of Technology Transfer 21 (1-2) (1996) 61-69. doi:10.1007/BF02220308.

URL http://link.springer.com/10.1007/BF02220308

[6] P. A. Gompers, J. Lerner, The Venture Capital Cycle, MIT Press, 2004.

URL https://books . google.com/books?id=yEAcswbX1fEC

[7] L. Mills, Global Trends in Clean Energy Investment - Q4 2014, Tech. rep., Bloomberg New Energy Finance, New York (2015).

URL https://data.bloomberglp.com/bnef/sites/4/2015/01/ Q4-investment-fact-pack.pdf

[8] Electricity data browser - Average retail price of electricity, Tech. rep., U.S. Energy Information Administration, Washington, D.C. (2016).

URL https://www .eia.gov/electricity/data/browser/

[9] U.S. Gasoline and Diesel Retail Prices, Tech. rep., U.S. Energy Information Administration, Washington, D.C. (2016).

URL/https://www.eia.gov/dnav/pet/pet\{_\}pri\{_\}gnd\{_\}dcus\{_\}nust__\}m . htm

[10] L. Story, An Oracle of Oil Predicts \$200-a-Barrel Crude - The New York Times (may 2008).

URL http://www.nytimes.com/2008/05/21/business/21oil.html? $\left\{\_\right\} r=0$

[11] 109th Congress of the United States, Energy Policy Act of 2005 (2005). URL https://www . congress .gov/109/plaws/publ58/PLAW-109publ58. $\mathrm{pdf}$

[12] National Academy of Sciences, Rising Above the Gathering Storm National Academies Press, Washington, D.C., 2005. doi:10.17226/11463.

URL http://www.nap.edu/catalog/11463/ rising-above-the-gathering-storm-energizing-and-employing-america-for 
[13] P. A. Gompers, J. Lerner, M. Blair, T. Hellmann, What Drives Venture Capital Fundraising? (1998). doi:10.2307/2534802.

URL http://www.jstor.org/stable/2534802?origin=

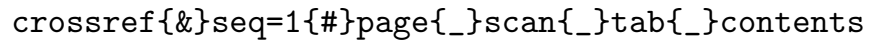

[14] P. Gompers, J. Lerner, Money chasing deals? The impact of fund inflows on private equity valuation, Journal of Financial Economics 55 (2) (2000) 281-325. doi:10.1016/S0304-405X (99)00052-5.

URL http://www.sciencedirect.com/science/article/pii/ S0304405X99000525

[15] U. C. Haley, D. A. Schuler, Government Policy and Firm Strategy in the Solar Photovoltaic Industry, California Management Review 54 (1) (2011) 17-38. doi:10.1525/cmr.2011.54.1.17.

URL http://cmr.ucpress .edu/content/54/1/17. abstract

[16] S. N. KAPLAN, A. SCHOAR, Private Equity Performance: Returns, Persistence, and Capital Flows, The Journal of Finance 60 (4) (2005) 17911823. doi:10.1111/j.1540-6261.2005.00780.x. URL http://doi.wiley.com/10.1111/j.1540-6261.2005.00780.x

[17] A. B. Hargadon, M. Kenney, Misguided Policy?, California Management Review 54 (2) (2012) 118-139. doi:10.1525/cmr.2012.54.2.118 URL http://cmr . ucpress . edu/content/54/2/118.abstract

[18] S. Ghosh, R. Nanda, Venture capital investment in the clean energy sector, Harvard Business School Entrepreneurial Management Working Paper (11$020)$.

[19] A. Marcus, J. Malen, S. Ellis, The Promise and Pitfalls of Venture Capital as an Asset Class for Clean Energy Investment: Research Questions for Organization and Natural Environment Scholars, Organization \& Environment 26 (1) (2013) 31-60. doi:10.1177/1086026612474956

URL http://oae.sagepub.com.prox.lib.ncsu.edu/content/26/1/31. refs 
[20] D. Mulcahy, B. Weeks, H. Bradley, We Have Met the Enemy... and He is Us: Lessons from Twenty Years of the Kauffman Foundation's Investments in Venture Capital Funds and the Triumph of Hope Over Experience, SSRN Electronic Journa doi:10.2139/ssrn.2053258

URL http://papers.ssrn . com/abstract=2053258

[21] M. Ewens, C. M. Jones, M. Rhodes-Kropf, The Price of Diversifiable Risk in Venture Capital and Private Equity, Review of Financial Studies 26 (8) (2013) 1854-1889. doi:10.1093/rfs/hht035.

URL http://rfs.oxfordjournals .org/cgi/doi/10.1093/rfs/hht035

[22] A. Ljungqvist, M. Richardson, The cash flow, return and risk characteristics of private equity (2003).

URL https://ideas.repec.org/p/nbr/nberwo/9454.html

[23] Crunchbase (2015).

URL http://www.crunchbase.com

[24] D. J. Cumming, J. G. MacIntosh, A cross-country comparison of full and partial venture capital exits, Journal of Banking \& Finance 27 (3) (2003) 511-548. doi:10.1016/S0378-4266(02)00389-8.

URL http://www.sciencedirect.com/science/article/pii/ S0378426602003898

[25] J. W. Bartlett, Fundamentals of Venture Capital, Vol. 17, Madison Books, 1999.

URL https://books.google.com/books?hl=en $\{\&\} l r=\{\&\}$ id= 8JkReEEiSbAC $\{\&\}$ pgis $=1$

[26] D. G. G. Smith, Control Over Exit in Venture Capital Relationships, SSRN Electronic Journa doi:10.2139/ssrn.272231.

URL http://papers. ssrn. com/abstract=272231

[27] J. C. Ruhnka, H. D. Feldman, T. J. Dean, The living dead phenomenon in venture capital investments, Journal of Business Venturing 7 (2) (1992) 
137-155. doi:10.1016/0883-9026(92)90009-G.

URL http://www.sciencedirect.com/science/article/pii/ $088390269290009 \mathrm{G}$

[28] J. H. Cochrane, The risk and return of venture capital, Journal of Financial Economics 75 (1) (2005) 3-52. doi:10.1016/j.jfineco.2004.03.006.

[29] P. Gompers, An analysis of compensation in the U.S. venture capital partnership Journal of Financial Economics 51 (1) (1999) 3-44. doi:10.1016/S0304-405X(98)00042-7.

URL http://www.sciencedirect.com/science/article/pii/ S0304405X98000427

[30] J. C. Kelleher, J. J. MacCormack, Internal rate of return: A cautionary tale, McKinsey Quarterly.

URL http://www.mckinsey.com/insights/corporate\{_ffinance/ internal\{_\}rate\{_\}of $\left\{_{-}\right\}$return $\left\{_{-}\right\} a\left\{{ }_{-}\right\}$cautionary\{_\}tale

[31] R. Nanda, M. Rhodes-Kropf, Financing risk and innovation, Management Science (Forthcoming).

[32] White House, Materials Genome Initiative for Global Competitiveness Tech. Rep. June, White House (2011).

URL

http://www. whitehouse.gov/blog/2011/06/24/ materials-genome-initiative-renaissance-american-manufacturing

[33] J. Eilperin, Why the clean tech boom went bust, Wired Magazine, February.

[34] A. Books, Energy Venture Capital Best Practices: Leading Vcs on Spotting Opportunity, Assessing Risk, And Exiting the Investment, Inside the Minds, Aspatore Books, 2006.

URL https://books . google.com/books?id=uhXNPAAACAAJ 
[35] S. Zhang, P. Andrews-Speed, M. Ji, The erratic path of the low-carbon transition in China: Evolution of solar PV policy, Energy Policy 67 (2014)

903-912. doi:10.1016/j.enpol.2013.12.063. 